Further Section

Stereotact Funct Neurosurg 1993;61:219-222

Contents Vol. 61, 1993 


\section{Stereotactic Neurosurgery}

Official Journal of the World Society for Stereotactic and Functional Neurosurgery

Official Journal of the American Society for Stereotactic and Functional Neurosurgery

Founded 1938 as 'Confinia Neurologica' by E.A. Spiegel Continued 1975-1988 as 'Applied Neurophysiology'

Editor

Ph.L. Gildenberg, Houston, Tex.

Assistant Editor

Patricia O. Franklin, Houston, Tex. 
Editorial Board

L.-E. Augustinsson, Göteborg J.-M. Besson, Paris

D. Bullard, Raleigh

E. Eideiberg, San Antonio

W.A. Friedman, Gainesville

J. Gybels, Leuven

E. Hitchcock, Birmingham P.J. Kelly, Rochester L. Laitinen, Vallentuna D.M. Long, Baltimore 
R. Marino, Säo Paulo M. Meglio, Rome

B. Meyerson, Stockholm

C. Ohye, Maebayashi

C. Ostertag, Freiburg

J. Siegfried, Zürich

A. Struppler, Munich

R.R. Tasker, Toronto

E.M. Todd, Arcadia

I.M. Turnbull, Vancouver

W.D. Willk Jfr., Galveston

KARGE N 


\section{Contents Vol. 61,1993}

No. $1 \quad$ Original Papers

Utility of Fragmented Human Fetal Tissue as a Potential Dopammergic Brain Graft in Parkinson's Disease

HogenEsch, R.I.; Staal, M.J.; Kema, I.P.; Buys, C.H.C.M.; Go, K.G

A Study of the Area of Distribution of the Deep Sensory Neurons of the Human Ventral

Thalamus

Seike, $\mathrm{M}$

Trajectory Angle in Stereotactic Thalamotomy

Taira, T.; Speelman, J.D.; Bosch, D.A

Registration of EEG Electrodes with Three-Dimensional Neuroimaging Using a Frameless,

Armless Stereotactic Wand

Barnett, G.H.; Kormos, D.W.; Steiner, C.P.; Morris, H

$\mathrm{g}$

A Simple System for Stereotactic Volumetrie Resection

Taira, T.; Kawamura, H.; Tanikawa, T.; Iseki, H

Letter to the Editor

Patil, A.A

Announcements

ther any

opy-

iting irect ince rs').

ad) 


\section{No. 2 Original Papers}

Neuroelectric Stimulation in Cerebral Palsy: Long-Term Quantitative Assessment

Harris, G.F.; Miliar, E.A.; Hemmy, D.C.; Lochner, R.C.

Experience with 509 Plate Electrodes Implanted Epidurally from $\mathrm{Ci}$ to $\mathrm{Li}$

Barolat, G

Nonvolumetric Stereotaxy-Assisted Craniotomy. Results in 50 Consecutive Cases

Barnett, G.H.; McKenzie, R.L.; Ramos, L; Pulmer, J.

Changes in Arterial Blood Pressure Induced by Percutaneous Thermocoagulation of the

Trigeminal Ganglion and Rootlets

Seijo, F.; Bulla, B.; Fernändez, C; Moreno, J.; Lopez, J.M ....

The Thalamocingular Loop: Recordings from the Past

Pagni, CA.; Canavero, $\mathrm{S}$ 
No. $3 \quad$ Original Papers

CT-Guided Stereotactic Biopsy of Nonenhancing Brain Lesions

Perez-Cruet, M.J.; Adelman, L.; Anderson, M.; Roth, P.A.; Ritter, A.M.; Saris, S.C. 105 CT and

Pathological Study on Radiofrequency-Induced Lesion in Cat Thalamus

Zhang, G.; Gou, Q

Analysis of Parameters for Epidural Spinal Cord Stimulation. 1. Perception and Tolerance

Thresholds Resulting from 1,100 Combinations

Tulgar, M.; Barolat, G.; Ketcik, B

Analysis of Parameters for Epidural Spinal Cord Stimulation. 2. Usage Ranges Resulting

from 3,000 Combinations

Tulgar, M.; Barolat, G.; Ketcik, B

Analysis of Parameters for Epidural Spinal Cord Stimulation. 3. Topographical Distribution of Paresthesiae A Preliminary Analysis of 266 Combinations with Contacts

Implanted in the Midcervical and Midthoracic Vertebral Levels

Tulgar, M.; He, J.; Barolat, G.; Ketcik, B.; Struijk, H.; Holsheimer, J

Announcement

No. $4 \quad$ Original Papers

Release of Neurotransmitters in the CNS by Spinal Cord Stimulation: Survey of Present

State of Knowledge and Recent Experimental Studies

Linderoth, B.; Stiller, C-O.; Gunasekera, L.; O'Connor, W.T.; Franck, J.; Gazelius, B.;

Brodin, E

Changes in Hypothalamic Met-Enkephalin Levels of Rats Induced by Painful Stimulation

and Morphine Treatment

Seijo, F.; Hernändez, L.C.; Del Valle, M.; Ayala, J.; Iglesias, L.; Fuente, T; Lopez, J.M. 171 Stereotactic Microsurgical Resection of Cerebral Lesions

Rees Cosgrove, G.; Steiner, L

Accuracy in Frame-Based and Frameless Stereotaxy

Kitchen, N.D.; Lemieux, L.; Thomas, D.G.T

Three-Dimensional Angiography for CT-Guided Stereotactic Procedures: A New System

Lacerte, D.; Picard, C

Author Index

Subject Index

Suppl. 1 Proceedings-of the 1992 Meeting of the Leksell Gamma Knife Society. Buenos Aires, Argentina, Maren 7-9, 1992

Editors: J.C. Ganz, Bergen; Philip L. Gildenberg, Houston, Tex.; Patricia O. Franklin, Houston, Tex. 